\title{
Mod en udvidelse af feminismen - nu også i Danmark?
}

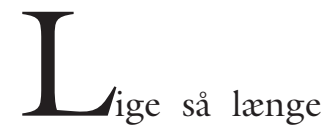

som feminismens definition af det gode kvindeliv har været på dagsordenen, har denne definition gennem sit behov for modbilleder abonneret på en århundredlang rivalisering mellem dét som den caribisk-britiske kulturforsker, Stuart Hall, har kaldt 'Vesten og Resten'. Især siden 1980'erne er behovet for modbilleder blevet problematiseret. I diskussioner af kvinder og forskellighed er feminismen åbent blevet udfordret af sorte kvinderetsforkæmpere $\mathrm{i}$ USA, af afrikanske feminister, indiske ditto m.fl. Skarpt sat op er spørgsmålet: Har man i Vesten allerede fundet definitionen på det gode kvindeliv, nemlig i feminismens hævdvundne dogmer om ligestilling mellem mænd og kvinder, og kan man derfor uden videre overføre disse dogmer til alle klodens samfund? Eller er der fortsat behov for at lytte, debattere og udvide sin forståelse af, hvad det gode kvindeliv er? Hvad vil ligestilling af kønnene egentlig sige?

At diskussionen af, hvad der betinger et 
godt liv for kvinder, fortsat er højaktuel, også i Danmark, kan man forvisse sig om, hvis man har observeret debatten om muslimske kvinders tørklæder, som i foråret 2008 har været mere intens end nogensinde. Efterhånden er denne debat blevet permanent, hvilket i sig selv er tankevækkende i forhold til den politisk-kulturelle polarisering, som den er et udtryk for, og som den i høj bidrager til at skabe og holde ved lige. Ifølge Rikke Andreassens analyse af, hvordan muslimske kvinder repræsenteres i danske medier (Andreassen 2006), er debatten uanfægtet af feministiske indsigter i forlængelse af 80'ernes og 90'ernes diversitetsdebat. Til trods for at enkelte af de muslimske kvinder, der bærer tørklæde er kommet til orde og til trods for en Miss Tørklæde konkurrence i DR, har mediedebattens formål samlet set ikke været at lytte og udvide forståelsen for de forskellige betingelser, som kvinder har i deres liv, men at docere gamle stereotyper om muslimske kvinder som uanset tid og rum - undertrykte af muslimske mænd, alene i kraft af tilslutningen til islam. Interessen for at finde nye tendenser og nye spor i den måde unge muslimske kvinder forvalter deres relation til mænd og til islam har formentlig dermed i dette forår nået et nyt lavpunkt.

\section{PrIVILIGERET ADGANG TIL}

\section{DEN SANDE UDLÆGNING}

Men den nye intensitet $\mathrm{i}$ diskussionen af muslimske kvinders tørklæde kan måske også skyldes, at muslimske kvinder - mange af dem unge og børn af indvandrere - nu også er aktive deltagere. Det har tilsyneladende fået en rakke mediepersonligheder til at insistere endnu kraftigere på, at netop de, og ikke deres som regel unge opponenter, kender tørklædets symbolik. En række feminister har sammen med diverse politikere fået megen spalteplads og taletid for samstemmigt at erklære, at det signalerer islam, politik og kvindeundertrykkelse. Det kan man konstatere i udtalelser fra en central placeret feminist i 70'ernes kvindebevægelse, nemlig forfatteren Bente Hansen (Information 9.maj 2007), fra formanden for 'Kvinder for Frihed' (der har 500 medlemmer), og fra Vibeke Manniche, som i flere tilfælde er kommet med lignende udtalelser: "Det tørklæde symboliserer uligheden mellem kønnene, at kvinden er manden underdanig, og det fratager kvinden hendes seksualitet. Det er et kyskhedsbælte på hovedet" (Politiken, d. 8.april 2008). Det er synspunkter, som også Lone Nørgård deler (se f.eks. kronik i Kristeligt Dagblad d. 11. maj 2007). Man fristes til at spørge: Hvor véd de det fra? Disse kvinder deler ikke kun en dogmatisk version af feminismen; de er også fælles om ikke at se nogen nødvendighed $\mathrm{i}$ at kvalificere deres synspunkter på muslimske kvinders tørklæde. Hvem kan egentlig siges at besidde den endegyldige viden og sandhed om dette tørklæde og dets symbolik? Eller hvem har ret til at udtale sig om det?

Sidstnævnte, meget relevante spørgsmål stiller iranske, men eksilerede Chahdortt Djavann i hendes korte skrift imod muslimske kvinders tørklæde - eller slør, som hun kalder det. Det er tilsyneladende i dette og lignende skrifter, at danske feminister af den mere dogmatiske skuffe henter deres skråsikre viden om slørets symbolik. Og danske feminister af denne skuffe godtager, af sikkert oplagte grunde, at denne kvinde har den største troværdighed som sandhedsvidne. Men heller ikke Djavann kvalificerer sine synspunkter, medmindre man godtager det følgende som sådan:

Fra jeg var tretten til jeg blev treogtyve blev der lagt bånd på mig: jeg var dømt til at være en muslimsk kvinde, undertrykt og indespærret bag slørets mørke. Fra jeg var tretten til jeg blev treogtyve. Og ingen skal nogensinde fortælle mig, at de var de lykkeligste år af mit liv (Djavann 2006: 5)

Djavann selv er tilsyneladende overbevist om at dét, at hun selv er blevet pålagt at gå 
med tørklæde i Iran, er tilstrækkeligt til stort set at overflødiggøre argumenter såvel som dokumentation for hendes synspunkter om at sløret er undertrykkende i resten af bogen. Således volder det hende ingen kvaler igen og igen at erklære, at islam via sløret indebærer kontrol af kvinders krop uden at påpege, hvorfra hun har den viden. Blot henviser hun uden nærmere reference til Koranen, og til at tilsløring fører til seksualisering. Samtidig anklager hun unavngivne franske intellektuelle for uberettiget at udtale sig om, hvorvidt tørklædet er skadeligt eller ej, en ret som hun naturligt tilskriver sig selv. Den form for adgang til uformidlet oplevelse er ellers for længst blevet udpeget som forfejlet, også af feministisk teori; uformidlet oplevelse er en illusion - ej heller har undertrykte kvinder en særlig privilegeret adgang til at definere virkeligheden.

\section{MUSLIMSKE FEMINISTER}

Anderledes forholder det sig med Sherin Khankans bog (2006) om hendes egne bestræbelser for at kende islams egentlige mening i en europæisk sammenhæng, såvel som Mette Bom og Shabana Motlanis bog (2006), formet som en dialog om, hvad de hver især mener, må være det gode kvindeliv. Begge bøger tager udgangspunkt i egne oplevelser, men uden at lægge det sandhedskrav for dagen som Djavann gør i sit, ganske vist meget korte skrift, tydeligvis skrevet på en følelse af indignation. Khankan, Bom og Motlani lægger hver især deres oplevelser åbent og engageret frem for læseren, og det er faktisk dét, som i høj grad bidrager til, at der i begge tilfælde er tale om læseværdige bøger, deres forskelligheder til trods. De gør det nemlig i anerkendelse af, at deres egne oplevelser har indvirkning på, hvordan de ser på verden. Begge bøger er samtidig et forsøg på at udfordre stereotype forestillinger om islam og om muslimske kvinder. Det kan man måske mene er et taknemmeligt job, når man ta- ger kendskabet til islam i almindelighed $\mathrm{i}$ betragtning.

Sherin Khankan er kandidat i religionshistorie, og det er gennem studierne, snarere end sit syrisk-fødte fædrene ophav, at hun begynder at følge dét hun kalder sufi-vejen til islam, som indebærer en anerkendelse af, at ens forståelse og tro løbende gennemgår en udvikling. Fortællingen om hendes gradvise tiltrækning til denne forståelse af islam er en meget personlig fortælling, men samtidig introducerer hun den begrebsverden, som er basal for at kende såvel islam som sufisme. Det gør hun - næsten - uden at gå på kompromis med akademiske krav om referencer og argumentation. Sufismen rummer en filosofisk tilgang til islam og opfordrer til, at man som troende søger meningen bag overfladen - og bag det konkrete, det regelbaserede. For Khankan er det vigtigt at fremhæve, hvordan man gennem sufismen kan være en troende muslim og samtidig forholde sig fleksibelt, $\mathrm{i}$ forståelsen udogmatisk, til sin religion. Således ser hun det også som en pointe i sig selv, at hun er formand og kvinde. Og således bærer Khankan ikke altid tørklæde, selvom hun mener, at man som muslimsk kvinde bør tilstræbe blufærdighed. Det er lejligheden, som byder hende at bære tørklæde eller ikke at bære tørklæde, ikke et vers i Koranen, som tilsyneladende udtaler en forventning om, at kvinder går med tørklæde. Sufismen bliver for Khankan en vej til at søge balancerede løsninger, også når det handler om forholdet mellem de to køn. Formidlingen af denne vej til islam udgør ét af bogens hovedærinder, og det kan nok være tiltrængt i en dansk offentlighed, som først og fremmest har forstået, at islam er en lovreligion. Inspireret af den 'europæiske muslim', Tariq Ramadan, udgør bogen som helhed et argument for, at islamisk inspireret politisk aktivisme skal forstås som en medspiller i den europæiske offentlighed; den er ikke og bør ikke gøres til en privatsag.

Khankan har til tider været en direkte 
part i kontroverser i medierne, for eksempel angående Islam og terrorisme og om mulighederne for at kombinere islam og demokratisk styre. Hun var en overgang medlem af det Radikale Venstre, men forlod forholdsvist hurtigt igen partiet. I 2001 etablerede hun sammen med religionsforsker, Henrik Plaschke, foreningen 'Kritiske Muslimer'. Derved opnåede hun mediernes opmærksomhed, og i dag kommenterer hun jævnligt i medierne. Indenfor blogverdenen er Khankan én af dem, som antimuslimske bloggere og andre højre-orienterede som Trykkefrihedsselskabets støtteskare ynder at mistænkeliggøre. Man kan, som nogle kritikere, mene, at hun først og fremmest iscenesætter sig selv. Et hurtigt blik på forsiden af hendes bog, hvor hun søger at illustrere et citat fra et sufi-forbillede gennem et foto af et sceneri, hvor hun selv holder en vandkaraffel $\mathrm{i}$ den ene hånd og en lampe i den anden, synes kun at bekræfte dette. Men for mig at se, selviscenesættelse eller ej, er det svært at afvise ærligheden i Khankans bestræbelse på at finde frem til de forsonende egenskaber i den muslimske tro.

Pakidanerdialogerne er ved første øjekast endnu én i rækken af bøger baseret på en email korrespondance, men i stedet for den spleen og causeri, som jeg fordomsfuldt forventer af den type bøger, behandler de i dialogen presserende konflikttemaer. De to forfattere er naboer i det indre København, og i bogen antager Mette Bom rollen som den skeptiske og åbenlyst fordomsfulde feministiske - udspørger angående muslimer. Udover modstillingen mellem de to kvinder er bogens idé tilsyneladende, at Shabana Motlani som person udfordrer en række ellers stivnede antagelser angående etnicitet, islam og køn. Motlani er en muslimsk kvinde, ja, men veluddannet og selvbevidst; hun har pakistansk baggrund, men er vokset op i Minnesota, USA og handler derfor ikke altid, som man i Danmark forventer at en pakistansk kvinde handler. $\mathrm{Og}$ hun taler ikke det sprog som de fleste med pakistansk afstamning i Danmak taler; hun er religiøs, men ikke enig i de ekstremistiske synspunkter, som generelt antages at herske blandt muslimer. Væsentligt for bogen er det desuden, at begge kvinder trækker på egne oplevelser af, hvordan kulturel forskellighed i befolkningen tackles i USA. Denne sammenligning falder i begge forfatteres øjne ikke ud til danskernes fordel. Samtidig udgør venskabet imellem dem en form for praktiseret modeksempel til den distance, som mestendels findes mellem muslimske indvandrere og befolkningen i Danmark i øvrigt. Et eksempel på en udveksling, hvor de to kvinder er uenige, handler ikke overraskende om, at nogle muslimske kvinder, Motlani inklusive, går med tørklæde. Mette Bom påpeger, at tørklædet er 'fjollet', og at kvinder ved at bære det afskærer sig fra at vise deres seksualitet. Samtidig har Bom svært ved at kapere, at Motlani og andre gør det som en indre trang til at opfylde en fordring, som de mener, er dem pålagt af Gud. Motlani svarer meget skarptseende, at det givetvis aldrig vil lykkes hende at overbevise Bom, som ikke selv er troende: "For en person som ikke sætter Gud eller religionen højest på dagsordenen, vil der nok aldrig være en god grund til at jeg går med hijab". Og hun fortsætter: "Men hvorfor skal andre egentlig have en god grund til noget, hvorfor skal jeg prøve at forklare det, hvis jeg bare kan retfærdiggøre det overfor mig selv?"(Bom \& Motlani 2006: 55). Dette udslag af individualistisk livssyn kapitulerer Bom overfor og accepterer, at tørklædet er et individuelt, omend ikke et frit valg.

De mest personlige indlæg i de to kvinders dialog er de mest interessante - detaljer i både Boms og Motlanis barne- og ungdomsliv, får os som læser til at forstå, hvordan de er blevet til de kvinder, som de er. Således er Motlani langt hen ad vejen blevet opdraget som en moderne amerikansk kvinde, i stand til at forsørge sig selv, mens Bom allerede i sin barndom etablerer dét, man i en dansk sammenhæng må kalde 
'usædvanlige venskaber', dvs. venskaber, der ikke holder sig til devisen om, at lige børn leger bedst. Således sander hun tidligt, at det ikke er alle, der besidder de privilegier, som præger hendes eget liv. Alligevel er noget af det mest rammende i bogen, at Motlanis mand, der er født i Danmark af pakistanske forældre, aldrig - aldrig! - har været indenfor i et dansk-dansk hjem. Altså før han fik Mette Bom og hendes kxreste som nabo. Et andet udsagn, der har brændt sig fast, er, at Motlani er træt - træt af altid at skulle forklare sig og sit tørklæde samtidig med, at hun erkender, at det vil være en nødvendighed - også fremover. En utilsigtet effekt af bogen er nok, at man efter endt læsning så udmærket forstår, hvorfor netop disse to kvinder etablerer et venskab - til trods for alle 'os og dem'-opdelinger i det danske samfund - mens det kan være svært at overføre deres erfaringer til ens egen nabo. Og som den største del af boligmassen er fordelt, er hun kun med ringe sandsynlighed en muslimsk, indvandret kvinde. Bogen er sympatisk i dens eksplicitte diskussion af, hvorvidt man på én gang kan være feminist og troende, udøvende muslim. Men jeg er i tvivl om, hvor vidt Bom ender med at betragte sin muslimske veninde som en feministisk medspiller. Kommer hun, trods sin tilslutning til et multikulturelt Danmark, længere end til at anerkende Motlani som den undtagelsesvist stærke muslimske kvinde? Denne usikkerhed opstår formentlig, fordi Bom renoncerer fra at replicere et par steder, hvor hun har lanceret 'fordomme', som Motlani der i sin selvforståelse er feminist, derefter henholdsvis diskuterer og tilbageviser. Det er et meget sigende paradoks, at Bom konstant må forsvare, at hun er feminist, "som om jeg helt frivilligt er trådt ind i et rædselskabinet", mens Motlani konstant må gøre gældende, at hun er feminist til trods for, at hun er troende muslim. Hvis parterne havde fanget dette paradoks, var de måske kommet et skridt længere i deres afsløring af tilgængelige positioner, når man er hhv. dansk, professionel middelklassekvinde og 'indvandrermuslimsk' professionel middelklassekvinde.

Men bøgerne forholder sig til meget mere end forholdet mellem kønnene, og således også til karikatur-krisen. Det er ikke denne krise, der skiller Bom og Motlani. Snarere end at acceptere, at krisen handlede om ytringsfrihed, slutter begge forfattere sig til det synspunkt, at krisen var et udslag af manglende respekt for troende muslimer. Derfor er det heller ikke bogens mest interessante del. Både Motlani og Bom udtrykker en form for sorg i den anledning, der måske bunder i afmagt, mens Khankans aktivistiske linje stiller hende stærkere. Ifølge Khankan kan man ikke forvente, at ikkemuslimer udviser adab (særlig agtelse) overfor Koranen og profeten, men man kan forvente, at de ikke direkte tilsøler dem. $\mathrm{Og}$ ifølge Khankan har karikaturkrisen været en anledning for muslimer, dog mest udenfor Danmark, til at demonstrere, at de hellere siger fra overfor det fællesskab som globalisering giver mulighed for, end de deltager under betingelser, hvor latterliggørelse og mistænkeliggørelse af deres religion hører til dagens orden.

\section{GRUNDLAGET FOR EN \\ UNIVERSEL FEMINISME}

Både Khankan og Bom/Motlani er konkrete eksempler på kvinder af i dag, som på linje med andre kvinder forsøger at forsone pragmatisme og principper i deres liv uden at gå på kompromis med egne drømme og ønsker. Viser de dermed, at troende muslimske kvinder godt kan være feminister?

Khankan understreger, at der ikke er én sand udlægning af, hvordan islam skal praktiseres, men at det er det 'indre tørklæde', den indre styrke, som skal give kvinder ligeværd og lige rettigheder med mænd (Khankan 2006: 144). I bogen gengiver hun sine interview med tre kvindelige konvertitter til islam, og de peger på linje med Motlani på tørklædet som bl.a. en personlig styrke- 
prøve, en dimension som indlysende bliver forstærket af den modstand mod det, som findes i f.eks. det danske samfund.

Hvis tørklædet i den forbindelse signalerer, at de er undertrykte, så er vi det nok alle. Khankans og Motlanis forsøg på at nå frem til denne forsoning er aktuelle bud på, hvordan feminismen kan udvides og blive mere inkluderende. Samtidig eksponerer deres bud forgangne versioner af feminismen, hvor mænd og religion éntydigt fremstår som dét, der skal bekæmpes for, at kvinder kan blive ligestillede.

Vores viden er situeret - den placerer sig i forlængelse af den kontekst og de sociale, økonomiske og politiske strukturer, som vi er en del af. Men hos nogle erklærede feminister ignoreres disse indsigter, i hvert fald så snart det drejer sig om, at grundlæggende antagelser hos feminismen udfordres. Faktisk skaber debatten om muslimske kvinders tørklæde selv den politiske symbolik, som i debatten påstås at klæbe sig til tørklædet som sådan. Desværre er det netop sådan denne tørklædedebat fungerer den politiserer tørklædet og vanskeliggør, at muslimske kvinder kan bære tørklædet af personlige-religiøse årsager, uden at det samtidigt opfattes som en politisk provokation. I øvrigt kan politiseringen være tiltrækkende for nogle, og faktisk tilskynde til at bære tørklæde. Er tørklædets symbolik endegyldig og evig, eller må man også indskrænke den tidslige horisont - og dermed erkende, at symboler kan ændre indhold alt efter tid og sted? Og dermed også åbne for, at det der sker i dag, når muslimske kvinder tager tørklæde på, faktisk kan vise sig at skabe nye signaler, nye forståelser og en ny symbolik. De kan med andre ord være en aktiv del af de forandringsprocesser, som også muslimer undergår. Der er i høj grad behov for at yngre, muslimske kvinder blander sig i, hvordan deres religion skal forstås og fortolkes. Kvinder for Frihed og deres meningsfæller tegner ikke hele det feministiske spektrum i Danmark, selvom deres synspunkter har tendens til at få gennemslagskraft i medierne. Og det er gennem artikuleringer som dem, der bliver presenteret af Khankan og Bom/Motlani, at vi far mulighed for til stadighed at undersøge grundlaget for fortsat at erklære, at feminismen har et budskab til kvinder af $i$ dag - uanset herkomst og tilhørsforhold.

\section{LITTERATUR}

- Andreassen, Rikke (2006): Der er et yndigt land. Medier, minoriteter og danskhed. Tiderne Skifter, København.

- Bom, Mette og Motlani, Shabana (2006): Pakidanerdialogerne. Asheschougs Forlag, København. - Djavann, Chahdortt (2006): Kast sloret! Akademisk Forlag, København.

- Khankan, Sherin (2006): Islam og forsoning. En offentlig sag. Lindhardt og Ringhof, København.

Connie Carøe Christiansen, adjunkt og pt. forsker i islamisk mode Institut for Samfund og globalisering Roskilde Universitetscenter 